\title{
多拠点生活者の居住動態パターン別の要求に関する研究
}

神戸大学大学院工学研究科前田 充紀 神戸大学大学院工学研究科近藤 民代

\section{I. 背景と目的}

近年、定額住み放題サービス (HS)、企業が管理・運営する ゲストハウスやホテルなどの拠点に定額で自由に滞在する ことができるサービスを利用した定住しない住まい方が登 場している。COVID-19 の流行以前はフリーランスなど働 く場所と時間にとらわれない一部の人に利用されていたサ ービスだが、企業のテレワーク推進により住まいと職場を 往復する生活の必要性が低下したため、このサービスを用 いて定住せずに生活する会社員の利用者も増加している。 ここからひとつの住まいに定住する住まい方だけでなく、 HS を利用し住居やHS の拠点を移動する住まい方、つまり 多拠点生活が多様化する住まい方のひとつになるだろう。

建築計画学研究では、家族関係や働き方の多様化により 住まいに求めるものが変化していることが示されている。 中村ほか (2020）1)で、情報通信技術の進歩によりコミュニ ティなどの社会デザインを踏まえたビルディングタイプを 計画する必要性が指摘されている。また、住宅政策学研究 では、雇用と所得の不安定さが増した現代において、戦後 の標準世帯に対応した持ち家取得による定住を前提とした 住宅政策体系が適応しなくなっていることが示されている。 平山 (2020） 2)は、公共賃貸セクターのストックの減少によ り、低家貨の住宅型は減少し低所得層の住まいの選択の自 由が奪われたことを問題点として挙げている。以上から、 子育て世帯の持ち家取得を推進するだけでなく、低所得・ 単身・借家といった多様な人々が場所や世帯にとらわれず 幅広い選択肢の中から住まい万を選べるシステムを構築し ていく必要がある。そのためには HS を利用した多拠点生 活がどのような住まい方なのかについて明らかにすること が、多様な人々が幅広い選択肢の中から住まい方を選べる システムを構築する手助けになると考えられる。そこで、 本研究では、以下の 2 つ焦点を当てる。

1. HS を利用した多拠点生活者の居住動態のパターンはど のようなものか。ここで、居住動態とは住居や拠点、働き 方などの関係からどのように多拠点を移動しているかを示 したものと定義する。

2. その生活が人々のどのような要求を満たすのか、また要 求していたもの以上に得られる利点にはどのようなものが あるのか

\section{II. 本研究の位置づけ}

本研究を取り巻く先行研究には主に 2 種類の研究がある。 1 つ目は住生活分野における多拠点生活の研究、2 つ目は

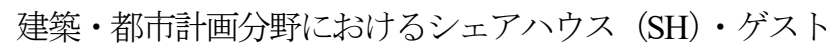
ハウス $(\mathrm{GH})$ の研究である。

（1）多拠点生活研究における本研究の位置づけ
先行研究には概ね「生活者の特徵」「滞在拠点の事業特性」 「滞在拠点地域の交流実態」を扱うものがあるが、本研究 は「生活者の特徴」の研究の延長に位置づけられる。(表 1) 多拠点生活を居住動態という視点で捉えている点が先行研 究と異なる。長谷川 (1993）3)の研究は、多拠点生活を居住 が立地する地域から類型化している。しかし、本研究はサ 一ビスの特性上、滞在する拠点の地域ではなく、ホームや 拠点、働き方などの関係から多拠点生活を動的に捉える。

表一 1 多拠点生活研究における本研究の位置づけ

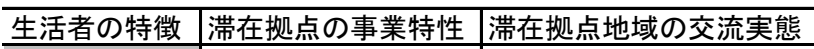

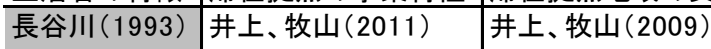
河内、森永 (2019)

本研究の位置づけ

（2） $\mathrm{SH} \cdot \mathrm{GH}$ 研究における本研究の位置づけ

先行研究は「入居者属性と住要求・満足度」、「空間計画と 行為の関係」、「立地が地域に及ぼしている影響」、「事業の 運営・管理」の 4 つに分類できる（表 2)。本研究では、HS の利用者を中心に「入居者属性と住要求・満足度」に着目 する。丁・小林 (2008) 4)はゲストハウスを選択する人の特 性および共有空間利用が居住者の交流に与える影響に着目 しているのに対し、本研究は HS の拠点内に留まらない、 移動する住まい方を動的に捉え、そのプロセスがどのよう に住居観を変容させているかを考察する点が異なる。

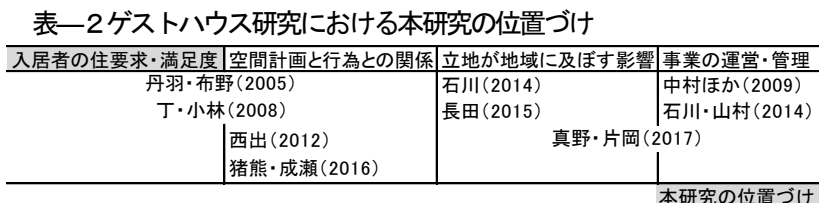

\section{III. 多拠点生活の分類}

本研究の問いを明らかにするために、多拠点生活を居住動 態パターン別に分類する（表 3)。HS が登場する以前から 多拠点生活という住まい方は存在していた。長谷川(1993) では、マルチハビテーションという言葉を用いて住まい方 を居住エリアと利用形態、住まいの建て方の観点から類型 化していた。しかし、HS において利用者は様々な選択肢の 中から拠点をその都度選択することができるために、居住 エリアや拠点の建て方ではなく居住動態という観点を用い ることで HS を利用した多拠点生活がどのような要求を持 って実践されているのかを全体像から把握する。

整理にあたつては、マルチハビテーションの類型をまと めた文献 1 （長谷川、1993）、2つの拠点両方に仕事場を持 つダブルローカルという住まい方をまとめた文献 2 (後藤、

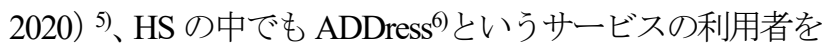


対象にアンケートが行われた「ADDress 多拠点生活 利用実 態レポート 2021 年版」7) (以下、文献3）を参照し、ホー ムの有無、HS 利用の有無から 4 つに分類し、それぞれの拠 点数、仕事場、拠点への要求を示した。ここで、ホームと は居を構える場所（住居の所有・賃貸双方を含み、住宅少 ブスク賃貸借契約は除く）を示す。

(1) 往復型

ホームを2つ持ち、ひとつを主たる住まい、もうひとつを 従たる住まいとして仕事や家族の生活条件に応じてそこを 往復する。住居の建て方は戸建てや集合住宅で、主たる住 まいに家族全員で住まい、従たる住まいは家族の全員また は一部が利用する。文献 1 から住まいいの要求としては、 平日は通勤するためにアクセスのよい利便性の高い都心、 週末は豊かな自然環境で過ごせる郊外というものがある。 さらに、郊外では、都心では得られない家族で独立した空 間のある良好な住環境の確保を求め、趣味や個別活動、保 養などを目的に過ごす。また、文献 2 は、余㗇活動を目的 としてもうひとつの住まいを利用するのではなく、両方を 仕事場の拠点として生活するダブルローカルという住まい 方について述べている。

（2）放浪型

放浪型とは、ホームを持たずに移動しながらの生活を指す (通称アドレスホッパー)。宿泊場所は、ホテル・ゲストハ ウス・マンスリーマンションなどで、フリーランスで会社 に出社する必要がなくパソコンさえあれば完結する仕事を している。家電や家具などの荷物が必要なく、賃貸契約と いった縛りがない。そのため、多くの人と出会いたい、趣 味を追求したいなど自身の要求に合わせ自分の好きな場所 に好きなタイミングで移動しながら生活することができる。

（3）リターン型

ホームを持ち、かつ HS を利用して、自身の目的に合わせ その都度 HS の拠点を選択、そして滞在し、自身の住居一 と帰る。ADDress 利用者全体のうち約半数はこの型に入り、 主たる住まいを貸貸住宅や持ち家、分譲マンションとして いる (文献 3$)$ 。拠点への要求としては、ワーケーションや 観光・休腵目的が挙げられる。往復型との違いは、滞在す る拠点が固定でないため同じ拠点の利用頻度が利用者の要 求によって変化する点である。さらに、要求に関して、往 復型は仕事をする場所とそうでない場所が明確に分けられ ていたが、リターン型では、拠点の共用部や個室でも働く ことを目的としている（文献3）。

（4）ホッピング型

ホームを持たずに HS の拠点を主な生活拠点とし生活する。 文献 3 によると、ADDress 利用者全体のうち約 4 割がこの 型に入る。

\section{IV. 調査方法}

国内の HS の主要事業者である ADDress の会員を分析対象 とし、SNS によるプレ調査 (配布 64 件、回答7 件) を 2021 年 2 月 1 日〜14 日の期間で行った。以下では、住居の所有

\section{表—3多拠点生活の分類}

\begin{tabular}{|c|c|c|c|c|}
\hline 軸 & 住復型 & リターン型 & $\begin{array}{l}\text { ホッピング } \\
\text { 型 }\end{array}$ & 放浪型 \\
\hline ホーム & 0 & 0 & $x$ & $x$ \\
\hline HS利用 & $x$ & 0 & 0 & $x$ \\
\hline 拠点数 & $\begin{array}{l}\text { 主:1つ } \\
\text { 副:1つ }\end{array}$ & $\begin{array}{l}\text { 住居:1つ } \\
\text { 拠点:2つ以上 }\end{array}$ & 2つ以上 & - \\
\hline 仕事場 & 職場 & $\begin{array}{l}\text { 職場、 } \\
コ \text { コワキング } \\
\text { スペース }\end{array}$ & $\begin{array}{l}\text { 職場、コ } \\
\text { ワーキング } \\
\text { スペース }\end{array}$ & $\begin{array}{l}\text { コワーキン } \\
\text { グスペース }\end{array}$ \\
\hline $\begin{array}{l}\text { 拠点 } \\
\text { 王 } \\
\text { 要求 }\end{array}$ & $\begin{array}{l}\text { 主:通勤利便性 } \\
\text { 副:自然環境、 } \\
\text { 余暇活動、別 } \\
\text { 荘利用、住環 } \\
\text { 境確保 }\end{array}$ & $\begin{array}{l}\text { 住居:通勤利便 } \\
\text { 性 } \\
\text { 拠点:余暇活動. } \\
\text { 別荘利用、リ } \\
\text { モートワーク }\end{array}$ & $\begin{array}{l}\text { 生活拠点、 } \\
\text { リモート } \\
\text { ワーク }\end{array}$ & 生活拠点 \\
\hline 通称 & $\begin{array}{l}\text { マルチハピ } \\
\text { テーション、 } \\
\text { ダプルローカ } \\
\text { ル、二拠点居 } \\
\text { 住 }\end{array}$ & & & $\begin{array}{l}\text { アドレス } \\
\text { ホッパー }\end{array}$ \\
\hline 参照 & $\begin{array}{l}\text { 長谷川(1993)、 } \\
\text { 後藤(2020) }\end{array}$ & $\begin{array}{l}\text { ADDressレポー } \\
\text { ト(2021) }\end{array}$ & $\begin{array}{l}\text {-ADDressL } \\
\text { ポート(2021) }\end{array}$ & \\
\hline
\end{tabular}

の有無から前章の居住動態パターン毎に回答 7件（利用者 (1) (7) を分類する。次に、対象者の住居、職業、HS に興 味を持ったきっかけに拠点の利用状況と感じる魅力がどの ように変化するかを示し、文献 3 の結果と比較し類似点と 相違点を比較寸る。そして、HS を利用した多拠点生活がど のように住まいに対する要求を変化させていくのかを考察 する。

\section{HS 利用者の居住動態パターンと要求}

居住動態を分類した結果、利用者(1)〜(4)がリターン型、利 用者(5)〜(7)がホッピング型となった。以下でパターン別の 住居、拠点別の利用状況、職業、拠点別の利用状況、HS に 興味を持ったきっかけ、拠点および非定住の魅力を示す。

（1）利用者(1)〜 (4)（リターン型）

利用者(1) (表4）の「景色のよい所で働きたくなった」とい う要求に対し「ワークスペースからの景色」の評価が 4 で

\begin{tabular}{|c|c|c|c|c|}
\hline & 年齢 & 38 & 興味を持ったきっかけ & \\
\hline \multirow[t]{3}{*}{ 住居 } & 所在地 & 兵庫県 & 定住の暮らしに疑問を感じた & $\mathrm{O}$ \\
\hline & 建て方 & シェアハウス & 田舎で暮らしたくなった & 0 \\
\hline & 同居人 & 非親族 & 自宅と職場の往復暮らしが退屈になった & \\
\hline \multirow[t]{5}{*}{ 職業 } & 職業1 & 撮影関係 & 景色のよい所で働きたくなった & 0 \\
\hline & 職場1 & なし & 在宅勤務がいやになった & \\
\hline & 職業2 & 映像制作 & ワンルームマンションが嫌になった & \\
\hline & 職場2 & なし & 過疎地域の活性化に貢献したい & 0 \\
\hline & リモートワーク割合[日/週] & 3 & その他 & 0 \\
\hline \multirow{5}{*}{ 利用状況 } & 利用日数 $[$ 日/月] & $16 \sim 20$ & \multirow{2}{*}{\multicolumn{2}{|c|}{$\begin{array}{l}\text { 元々、海外を含めたデジタルノマドの生活に関心があ } \\
\text { 以、日本国内サービスもトライしてみたかた。 }\end{array}$}} \\
\hline & 利用拠点数 & $11 \sim 20$ & & \\
\hline & よく利用する地域 & 南関東 & \multirow{3}{*}{\multicolumn{2}{|c|}{ 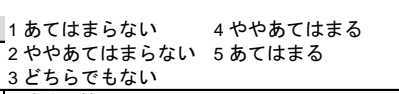 }} \\
\hline & 開始時期 & 2020年4月 & & \\
\hline & & & & \\
\hline \multicolumn{3}{|c|}{ 拠点の魅力 } & \multicolumn{2}{|l|}{ 非定住の魅力 } \\
\hline \multicolumn{2}{|c|}{ ワークスペースからの景色 } & 4 & 家族の役割から解放される & 1 \\
\hline \multicolumn{2}{|c|}{ 家守の人柄 } & 4 & 在宅ワークでは仕事モードにならな & 4 \\
\hline \multicolumn{2}{|c|}{ 近くに美味しい飲食店がある } & 4 & $2 つ の$ 切り替えのために場所を変え & 4 \\
\hline \multirow{2}{*}{\multicolumn{2}{|c|}{ 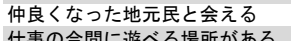 }} & 4 & オンとオフの混在が心地よい & 4 \\
\hline & & 4 & 日常からの逸脱が仕事の創造性を向上 & 4 \\
\hline \multicolumn{2}{|c|}{ 自然に触れられる } & 5 & 未知の世界と出会える & 5 \\
\hline \multicolumn{2}{|c|}{ 家守からの情報がある } & 4 & 異なる業種や職種の人と繋がれる & 5 \\
\hline \multicolumn{2}{|c|}{ 色んな人との出会いがある } & 5 & 持ち物が減って身軽になる & 4 \\
\hline \multicolumn{2}{|c|}{ 複数の行為が1拠点に完結している } & 5 & その他 & \\
\hline
\end{tabular}


あることから、HS の拠点は利用者(1)の要求を満たしてい る。しかし、魅力についてより高い評価であるのは「色ん な人との出会いがある」異なる業種や職種の人と繋がれる」 といった人と出会うことに関する内容である。

利用者(2)（表 5）の「田舎で暮らしたくなった」「田舎も 悪くないと思うようになった」という要求に対し、「近くに 美味しい飲食店がある」「仲良くなった地元民と会える」「自 然に触れられる」の評価から、(2)は地域の観光や地元民と の交流よりも都心にはない自然の中での生活を HS の拠点 に求めている。

\begin{tabular}{|c|c|c|c|c|}
\hline & 年齢 & 40 & 興味を持ったきっかけ & \\
\hline \multirow[t]{3}{*}{ 住居 } & 所在地 & 奈良県 & 定住の暮らしに疑問を感じた & 0 \\
\hline & 建て方 & シェアハウス & 田舎で暮らしたくなった & 0 \\
\hline & 同居人 & その他親族 & 自宅と職場の往復暮らしが退屈になった & 0 \\
\hline \multirow[t]{5}{*}{ 職業 } & 職業1 & 会社員 & 景色のよい所で働きたくなった & 0 \\
\hline & 職場1 & 東京都 & 在宅勤務がいやになった & \\
\hline & 職業2 & - & ワンルームマンションが嫌になった & \\
\hline & 職場2 & - & |過疎地域の活性化に貢献したい & \\
\hline & リモートワーク割合[日/週] & 3 & その他 & \\
\hline & 利用日数[日/月] & $6 \sim 10$ & & \\
\hline \multirow[t]{4}{*}{ 利用状況 } & 利用拠点数 & $6 \sim 10$ & & \\
\hline & よく利用する地域 & 南関東 & \multirow{3}{*}{\multicolumn{2}{|c|}{ 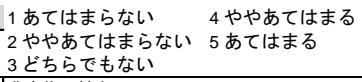 }} \\
\hline & 開始時期 & 2020年1月 & & \\
\hline & & & & \\
\hline \multicolumn{3}{|c|}{ 拠点の魅力 } & \multicolumn{2}{|l|}{ 非定住の魅力 } \\
\hline \multicolumn{2}{|c|}{ ワークスペースからの景色 } & 4 & 家族の役割から解放される & 2 \\
\hline \multicolumn{2}{|c|}{ 家守の人柄 } & 4 & 在宅ワークでは仕事モードにならお & 3 \\
\hline \multicolumn{2}{|c|}{ 近くに美味しい飲食店がある } & 3 & $2 つ$ 切り替えのために場所を変え & 3 \\
\hline \multirow{2}{*}{\multicolumn{2}{|c|}{ 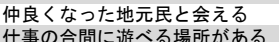 }} & 3 & オンとオフの混在が心地よい & 3 \\
\hline & & 4 & 日常からの逸脱が仕事の創造性を向上 & 4 \\
\hline \multicolumn{2}{|c|}{ 自然に触れられる } & 4 & 未知の世界と出会える & 5 \\
\hline \multicolumn{2}{|c|}{ 家守からの情報がある } & 4 & 異なる業種や職種の人と繋がれる & 5 \\
\hline \multicolumn{2}{|c|}{ 色んな人との出会いがある } & 5 & 持ち物が減って身軽になる & 2 \\
\hline \multicolumn{2}{|c|}{ 複数の行為が1拠点に完結している } & 4 & その他 & 0 \\
\hline
\end{tabular}

利用者(3)（表6）の「日常に刺激がほしい」という要求に 対して、(1)や(2)に比べ利用日数・拠点利用数が少ないが「色 んな人との出会いがある」異なる業種や職種の人と繋がれ る」の評価が最も高いことから、様々な人と出会うことで 刺激を得るためには、必ずしも利用拠点数を増やす必要は ない。また、「景色の良いところで働きたくなった」「在宅 勤務がいやになった」への要求がなく「ワークスペースか らの景色」「オンとオフの混在が心地よい」の評価から、働 く目的ではHS の拠点を利用していない。一方、リターン 型でホームがあるにも関わらず、持ち物が減って身軽にな る」とは具体的にどのような点を身軽だと感じているのか

\begin{tabular}{|c|c|c|c|c|}
\hline & 年齢 & 53 & 興味を持ったきつかけ & \\
\hline \multirow[t]{3}{*}{ 住居 } & 所在地 & |東京都 & 定住の暮らしに疑問を感じた & 0 \\
\hline & 建て方 & て(持ち家) & 田舎で暮らしたくなった & \\
\hline & 同居人 & その他親族 & 自宅と職場の往復暮らしが退屈になった & \\
\hline \multirow[t]{5}{*}{ 職業 } & 職業1 & リリーランス & 景色のよい所で働きたくなった & \\
\hline & 職場1 & |東京都 & 在宅勤務がいやになった & \\
\hline & 職業2 & - & ワンルームマンションが嫌になった & \\
\hline & 職場2 & & 過疎地域の活性化に貢献したい & \\
\hline & リモートワーク割合[日/週] & 7 & その他 & 0 \\
\hline & 利用日数 $[$ 日/月] & $6 \sim 10$ & \multicolumn{2}{|l|}{ 日常に刺激が欲しかった } \\
\hline \multirow[t]{4}{*}{ 利用状況 } & 利用拠点数 & $1 \sim 5$ & \\
\hline & よく利用する地域 & 南関東 & & \\
\hline & 開始時期 & 2019年4月 & \multirow{2}{*}{\multicolumn{2}{|c|}{$\begin{array}{ll}1 \text { 1 あてはまらない } & 4 \text { ややあてはまる } \\
2 \text { 2ややあてはまらない } & 5 \text { あてはまる } \\
3 \text { どちらでもない } & \end{array}$}} \\
\hline & & & & \\
\hline \multicolumn{3}{|c|}{ 拠点の魅力 } & \multicolumn{2}{|l|}{ 非定住の魅力 } \\
\hline \multicolumn{2}{|c|}{ ワークスペースからの景色 } & 1 & 家族の役割から解放される & 4 \\
\hline \multicolumn{2}{|c|}{ 家守の人柄 } & 5 & 在宅ワークでは仕事モードにならな & \\
\hline \multicolumn{2}{|c|}{ 近くに美味しい飲食店がある } & 3 & $2 つ$ つ切り替えのために場所を変え & 3 \\
\hline \multicolumn{2}{|c|}{ 仲良くなった地元民と会える } & 4 & オンとオフの混在が心地よい & 3 \\
\hline \multicolumn{2}{|c|}{ 仕事の合間に遊べる場所がある } & 4 & 日常からの逸脱が仕事の創造性を向上 & 5 \\
\hline \multicolumn{2}{|c|}{ 自然に触れられる } & 4 & 未知の世界と出会える & 5 \\
\hline \multicolumn{2}{|c|}{ 家守からの情報がある } & 4 & 異なる業種や職種の人と繋がれる & 5 \\
\hline \multicolumn{2}{|c|}{ 色んな人との出会いがある } & 5 & 持ち物が減って身軽になる & 5 \\
\hline \multicolumn{2}{|c|}{ 複数の行為が1拠点に完結している } & 1 & その他 & \\
\hline
\end{tabular}

\section{が不明である。}

利用者(4)（表 7）について、「ワンルームマンションが嫌 になった」という要求と「在宅勤務が嫌になった」わけで はないことからリモートワークの場としてホームの代わり に HS の拠点を求めていたわけではない。しかし(1)と同様 に HS の拠点は(4)の働く環境に対する要求を満たしている。

\begin{tabular}{|c|c|c|c|c|}
\hline & 年齢 & 31 & 興味を持ったきっかけ & \\
\hline \multirow[t]{3}{*}{ 住居 } & 所在地 & |愛知県 & 定住の暮らしに疑問を感じた & $\mathrm{O}$ \\
\hline & 建て方 & 合住宅(賃貸) & 田舎で暮らしたくなった & \\
\hline & 同居人 & |その他親族 & 自宅と職場の往復暮らしが退屈になった & \\
\hline \multirow[t]{5}{*}{ 職業 } & 職業1 & 講師 & 景色のよい所で働きたくなった & 0 \\
\hline & 職場1 & 東京都 & 在宅勤務がいやになった & \\
\hline & 職業2 & 制作 & ワンルームマンションが嫌になった & 0 \\
\hline & 職場2 & 東京都 & 過疎地域の活性化に貢献したい & \\
\hline & リモートワーク割合[日/週] & 6 & その他 & \\
\hline & 利用日数[日/月] & $11 \sim 15$ & & \\
\hline \multirow[t]{4}{*}{ 利用状況 } & 利用拠点数 & $1 \sim 5$ & & \\
\hline & よく利用する地域 & 南関東 & & \multirow{3}{*}{$\begin{array}{l}4 \text { ややあてはまる } \\
5 \text { あてはまる }\end{array}$} \\
\hline & 開始時期 & 2021年1月 & 1 あてはまらない & \\
\hline & & & $\begin{array}{l}2 \text { 2ややあてはまららない } 5 \text { あてはま } \\
3 \text { どちらでもない }\end{array}$ & \\
\hline \multicolumn{3}{|c|}{ 拠点の魅力 } & 非定住の魅力 & \\
\hline \multicolumn{2}{|c|}{ ワークスペースからの景色 } & 5 & 家族の役割から解放される & 1 \\
\hline \multicolumn{2}{|c|}{ 家守の人柄 } & 5 & 在宅ワークでは仕事モードにならお & 3 \\
\hline \multicolumn{2}{|c|}{ 近くに美味しい飲食店がある } & 5 & $2 つ$ の切り替えのために場所を変え & 4 \\
\hline \multicolumn{2}{|c|}{ 仲良くなった地元民と会える } & 5 & オンとオフの混在が心地よい & 5 \\
\hline \multicolumn{2}{|c|}{ 仕事の合間に遊べる場所がある } & 4 & 日常からの逸脱が仕事の創造性を向上 & 5 \\
\hline \multicolumn{2}{|c|}{ 自然に触れられる } & 5 & 未知の世界と出会える & 4 \\
\hline \multicolumn{2}{|c|}{ 家守からの情報がある } & 5 & 異なる業種や職種の人と繋がれる & 5 \\
\hline \multicolumn{2}{|c|}{ 色んな人との出会いがある } & 5 & 持ち物が減って身軽になる & 5 \\
\hline \multicolumn{2}{|c|}{ 複数の行為が1拠点に完結している } & 5 & その他 & 0 \\
\hline
\end{tabular}

\section{（2）利用者(5)〜 (7)（ホッピング型)}

利用者(5)（表 8）の「ツアーガイドとして日本中の観光地 や面白い人たちとの繋がりを広げたいと思った」という要 求に対する「色んな人との出会いがある」「異なる業種や職 種の人と繫がれる」の評価と自由記述から HS を利用した 生活がその要求を満たしている。しかし、「家守の人柄」「家 守からの情報がある」と「仲良くなった地元民と会える」 の評価から、(5)は繋がりの内容として、家守から地域の情 報を得ることを求めていない。

表—8利用者5)
(ホホッピング型)

利用者6)（表9）について、「家守の人柄」「仲良くなった地 元民と会える」色んな人との出会いがある」の評価から HS を利用した生活は家守や他の利用者に加えて地元民と会え る点も魅力になっている。一方、「東京に疲れた」という要 求に対する自由記述からは、どのように見え方が変わった 
